\title{
Description of two new species of the chironomid midges collected from the Tama River, Tokyo (Diptera, Chironomidae)
}

\author{
Tadashi Kobayashi* and Manabu SasA** \\ ${ }^{*}$ Caritas Junior and Senior High School, Tama-ku, Kawasaki 214, Japan \\ ** Toyama University of International Studies, Oyama-cho, Toyama 930-12, Japan
}

(Received: April 23, 1990)

Key words: Chironomidae, new genus, new species, freshwater entomology.

\begin{abstract}
While extensive surveys of the chironomid midges breeding in and around the Tama River were carried out by the senior author, two new species were collected on the Tama Hills along middle reaches of the river, Paratendipes tamafuscus sp. nov. and Tokyobrillia tamamegaseta gen. et sp. nov., as described in the text.
\end{abstract}

\section{INTRODUGTION}

The species of the chironomid midges breeding in and around the Tama River, Tokyo, were studied extensively by Sasa and his coworkers (1980-1983), with special references to their distribution in relation to the degree of pollution with sewage waters. More recently, studies on the chironomids found in the Tama Hills along the middle reaches of the river have been conducted by the senior author, and some 80 species have already been collected and identified. Among them, the morphology of the following new species, Paratendipes tamafuscus sp. nov., and Tokyobrillia tamamegaseta gen. et sp. nov., are described in the present paper.

The nomenclature of adult males of Chironomidae, the methods of mounting the specimens on slides, and of standard measurements are the same as described by Sasa (1989). The key characters for classification of the chironomids mostly followed the system described by Brundin (1956), Pinder (1978)

* 小林 貞：カリタス学園（干214 川崎市多摩区中 野島 1800)

** 佐々 学: 富山国際大学（宁930-12 富山県上新 川郡大山町東黒牧 65-1) and Sasa (1989). The type specimens are being deposited in Toyama Science Museum.

\section{DESGRIPTION}

\section{Paratendipes tamafuscus sp. nov.} (Fig. 1)

Four males emerged from bottom samples of the Tama River collected at Ikuta, Tamaku, Kawasaki (Kanagawa). Holotype: No. A 199:51, emerged Oct. 25, 1989. Paratypes: No. A 199:52-54, emerged Sep. 7, Sep. 30 and Oct. 28, 1989.

BL 2.98-3.68 (3.39 in average of 4$) \mathrm{mm}$. WL 1.51-1.82 (1.65) $\mathrm{mm}$. Body largely dark brown; ground color of scutum brown, scutal stripes dark brown, scutellum brown, postnotum and abdomen uniformly dark brown; wing unmarked, halteres brown; front femur yellow for basal $2 / 3$ and brown for distal $1 / 3$, front tibia brown for basal $1 / 3$ and yellow for distal $2 / 3$, and with an apical brown ring; front tarsi I and II largely yellow and each with an apical brown ring, III basally yellow and largely brown, IV and V entirely brown; femora, tibiae, tarsi I, II and III of middle and hind legs largely yellow and each with an apical dark ring. 


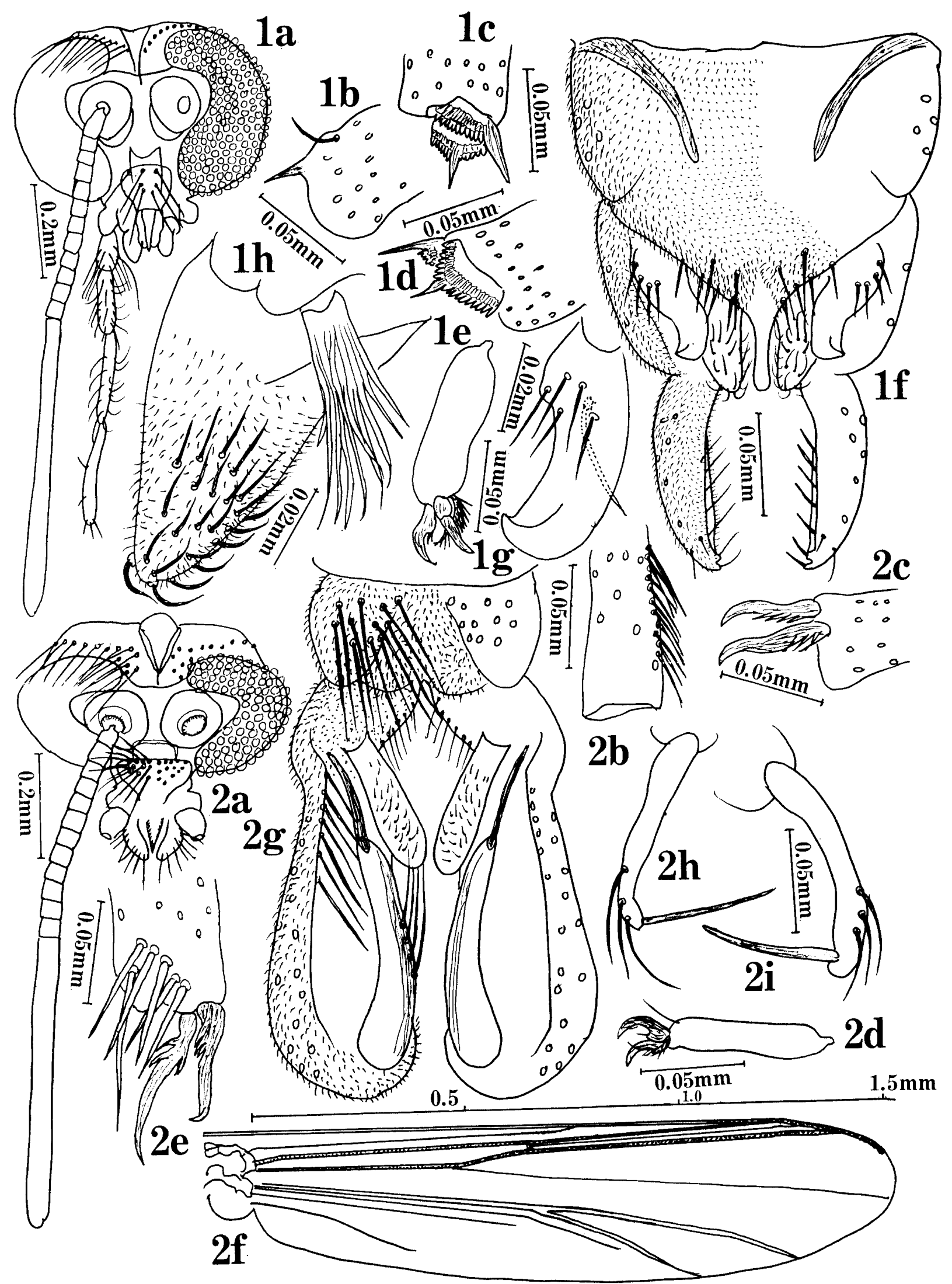

Figs. 1 and 2. 
Head in Fig. 1-a. Frontal tubercles absent. Eyes bare, ER 0.19-0.39 (0.23). Antenna with 13 flagellar segments. AR 1.37-1.54 (1.48), AHR 0.48-0.52 (0.50). Palp well developed, $\mathrm{P} / \mathrm{H}$ ratio (length of palp divided by width of head) $0.95-1.25(1.10)$, SO 8-12 (9.1), CL 7-10 (9.3), Antepronotum with 1,2 or 3 (most frequently 1 , mean 1.4) lateral seta (unusual character as a member of Chironomini). DM 16-20 (18.0), DL 9-13 (10.3), PA 3-5 (4.0). SC 9 (in 1 specimen) or 10 (in 3 ). Wing bare, without dark marks, squama bare in 3 specimens, with one seta in one specimen. $\mathrm{R} 2+3$ ending closer to tip of R1 than to tip of R4+5. RR $0.19-0.29(0.26)$. Tip of costa distal to tip of $\mathrm{Cu} 1, \mathrm{R} / \mathrm{Cu}$ 1.05-1.10 (1.08). VR 1.091.13 (1.10). Tip of front tibia (Fig. 1-b) with a small, narrow and sharply pointed terminal process. Tip of middle and hind tibiae (Fig. 1-c, d) with two comb scales, both with a short spur. Pulvilli vestigial, claws and empodium well developed (Fig. 1-e). fLR $1.48,1.53$, mLR $0.55-0.58(0.56)$, hLR $0.69-0.73(0.71)$, fTR $0.27,0.28$, fBR 4.7, 5.3, mBR 3.6-6.6 (5,0), hBR 4.3-4.9.

Hypopygium in Fig. 1-f. Ninth tergite without long setae in the central portion, and with 6 short setae on both sides of anal point. Bands of ninth tergite widely separated in the middle. Dorsal appendage (Fig. 1-g) somewhat plate-like but apically hooked, with 5 short setae on dorsal side near the base, and one long and curved seta on ventral side near the base. Ventral and median appendages as in Fig. 1-h, the former stout and somewhat conical and with some 20 short and recurved setae, the latter brush-like and bearing some 10 short, simple setae. Gonostylus widest at about basal $1 / 3$ and apically pointed, inner margin slightly concave and lateral margin smoothly convex, with two rows of short setae along inner margin.

Remarks. This species is considered as belonging to the genus Paratendipes Kieffer, 1911 , since it has general characteristics of the tribe Ghironomini, but as shown in the key compiled by Sasa (1989), wings are bare and without dark marks, antenna with 13 flagellar segments, frontal tubercles absent, squama bare, both of the terminal comb scales of middle and hind tibiae with a short spur, pulvilli absent, both dorsal and ventral appendages are the Chironomini-type but hypopygium has median appendages such as seen in species of the tribe Tanytarsini. Of the two species of this genus recorded from Europe by Pinder (1978), this species is more closely related to $P$. nudisquama (Edwards, 1929) in that the anal point is not constricted basally and dorsal appendage is not bottle-shaped, but in the latter, gonostylus is slender and not broadened medially, dorsal appendage is differently shaped and with more numerous inner and lateral setae (Fig. 165B; Pinder, 1978). One species of this genus, $P$. tamayubai, was recorded also from the Tama River by Sasa (1983a), but its dorsal appendage is bottle-shaped and quite different from that of the present species.

\section{Tokyobrillia gen. nov.}

This is a new genus within the Brilliacomplex of the tribe Orthocladiini, subfamily Orthocladiinae. Four genera have been recognized within this complex: Brillia Kieffer, 1913; Eurycnemus van der Wulp, 1874; Euryhapsis Oliver, 1981; and Xylotopus Oliver, 1982. They are mostly characterized by that wings bear macrotrichiae, antepronotum with dorsal setae, terminal spurs of middle and hind legs are barbed, inner lobe of gonocoxite is long, narrow, and finger-like, anal point is absent, and gonostylus is bifurcate. The present genus shares most of these morphological characteristics with the

Fig. 1 Paratendipes tamafuscus sp. nov.

$\mathrm{a}$ : head. b: tip of front tibia. c: tip of middle tibia. $\mathrm{d}$ : tip of hind tibia. $\mathrm{e}$ : hind tarsus $\mathrm{V}$, showing empodium and claws. $\mathrm{f}$ : hypopygium. $\mathrm{g}$ : right dorsal appendage. $\mathrm{h}$ : ventral appendage.

Fig. 2 Tokyobrillia tamamegaseta sp. nov.

a: head. b: tip of front tibia. c: tip of middle tibia. d: middle tarsus V. e: tip of hind tibia. f: wing. $\mathrm{g}$ : hypopygium. $\mathrm{h}, \mathrm{i}$ : left and right gonostylus. 
above genera, but differs essentially by that gonostylus is not bifurcate but simple, and bears very long terminal spine (megaseta) and 3 or 4 very long setae. A key for differentiating the previously known 4 genera were given by Cranston et al. (1989) .

Type species. Tokyobrillia tamamegaseta sp. nov., monotypic.

\section{Tokyobrillia tamamegaseta sp. nov.} (Fig. 2)

Two males were collected with a light trap set at the side of the Tama River, Masugata, Tama-ku, Kawasaki (Kanagawa), one on Oct. 13, 1988 (holotype: No. A 199:56), and another on Aug. 29, 1989 (paratype: No. A 199:57). BL 2.56, $2.97 \mathrm{~mm}$, WL 1.43, $1.53 \mathrm{~mm}$. Body entirely pale yellow, excepting eyes and tibial spurs, which are dark brown. Head in Fig. 2-a. Eyes bare, each with a long dorsomedial projection, ER 0.23, 0.39 . Antenna with 13 flagellar segments, AR 1.61, 1.52, AHR 0.59, 0.57. Palp lost in both specimens. SO $8: 10,12: 12$, CL 16, 24. Antepronotum with 2 or 3 dorsal setae, and 5 lateral setae. DM $0,0, \mathrm{DL}$ $28: 30,24: 24$. PA $4: 4,5: 5$, SC 16,12 . Wing membrane without dark marks but thickly covered with macrotrichiae. SQ 7:7, 5:5. Wing venation in Fig. 2-f (macrotrichiae omitted) ; costa extending much beyond tip of $\mathrm{R} 4+5$ and to near tip of wing; tip of $\mathrm{R} 4+5$ distal to tip of $\mathrm{Cu} 1, \mathrm{R} / \mathrm{Cu} 1.12,1.05$. $\mathrm{R} 1, \mathrm{R} 2+3$ and $\mathrm{R} 4+5$ are very narrowly separated, $R R$ 0.50, 0.55. Cross vein $r-m$ is extremely long, and its fork is much proximal to $\mathrm{fCu}, \mathrm{VR} 1.70,1.61$. Front tibia with strong hair tuft subapically, and with truncate apex but without apical spur (Fig. 2-b). Middle tibia with two strong and barbed apical spurs of subequal length (Fig. 2-c). Hind tibia with two long and barbed apical spurs, and with 3-6 simple and irregularly arranged spurs (Fig. 2-e; probably a primitive form of terminal comb of other Orthocladiinae). Front tarsi lost in both specimens. mLR 0.70 , hLR 0.74. Terminal claws are well developed but empodium is minute, pulvilli absent (Fig. 2-d) .

Hypopygium in Fig. 2-g. Ninth tergite without anal point, and with 22, 24 strong setae. Inner lobe of gonocoxite very long, narrow, finger-like, and covered thickly with microtrichiae. Gonocoxite very large and apically expanded. Gonostylus long, slender, smoothly curved, with 4 very long setae arising at about middle, and with an extremely long apical spur (63:65 $\mu \mathrm{m}$ long in holotype, $62 \mu \mathrm{m}$ long in paratype; Fig. 2-h, i).

Remarks. This species can be easily differentiated from all the previously known species of Orthocladiini by morphological characteristics given in the definition of this new genus, Tokyobrillia.

\section{REFERENGES}

Brundin, L. (1956): Zur Kenntinis der Orthocladiinae. Rep. Inst. Freshwater Res. Drottingholm., 37: 1-175.

Cranston, P. S., D. R. Oliver and O. A. Saether (1989): The adult males of Orthocladiinae of the Holarctic Region-Keys and diagnosis. Entomol. Scand. (Suppl.), 34: 175-352.

Edwards, F. W. (1929): British non-biting midges. Trans. R. Entomol. Soc. London, 77: 279-429.

Pinder, L. C. V. (1978): A key to adult males of British Chironomidae. Freshwater Biol. Assoc. Sci. Publ., No. 37: 1-169 (Figs. 189).

Sasa, M. (1980): Studies on chironomid midges of the Tama River. Part 2. Description of 20 species of Chironominae recovered from a tributary. Res. Rep. Natl. Inst. Environ. Stud., No. 13: 9-107.

Sasa, M. (1981a): Studies on chironomid midges of the Tama River. Part 3. Species of the subfamily Orthocladiinae recorded at the summer survey and their distribution in relation to the pollution with sewage waters. Res. Rep. Natl. Inst. Environ. Stud., No. 29: 1-78.

Sasa, M. (1981b): Studies on chironomid midges of the Tama River. Part 4. Chironomidae recorded at a winter survey. Res. Rep. Natl. Inst. Environ. Stud., No. 29: 79-148.

Sasa, M. (1983a): Studies on chironomid midges of the Tama River. Part 5. An observation on the distribution of Chironominae along the main stream in June, with description of 15 new species. Res. Rep. Natl. Inst. Environ. Stud., No. 43: $1-67$.

Sasa, M. (1983b) : Studies on chironomid midges of the Tama River. Part 6. Description of species of the subfamily Orthocladiinae recovered from the main stream in the June survey. Res. Rep. Natl. Inst. Environ. Stud., No. 43: 69-99.

Sasa, M. (1989) : Chironomidae of Japan: Checklist of species recorded, key to males and taxonomic notes. Res. Rep. Natl. Inst. Environ. Stud., No. 125: 1-177. 


\section{摘要}

多摩川から採集したユスリカの 2 新種について

多摩川は水源を山梨県の山間部に発し，その中流部 からは市街地からの下水の混入によりしだいに水質の 污染がす寸むという型の典型的な河川の一つである が，これに発生するユスリカの種類と分布について
は，佐々ら (1980〜 1983) のくわしい調查があり，最 近には小林の研究も行われて, すでに80をこえる種類 の発生が確かめられている.今回は1988年から1989年 にかけて，小林が採集した標本のうち次の 2 種類（後 者は新属）について記載を行った. その形態的特徵, および図版は本文に記したとおりである。

Paratendipes tamafuscus sp. nov.

Tokyobrillia tamamegaseta gen. et sp. nov. 